\title{
Down by the riverside: urban riparian ecology
}

\author{
Peter M Groffman ${ }^{1}$, Daniel J Bain ${ }^{2}$, Lawrence E Band ${ }^{3}$, Kenneth T Belt ${ }^{4}$, Grace S Brush ${ }^{2}$, J Morgan Grove ${ }^{5}$, \\ Richard V Pouyat ${ }^{4}$, Ian C Yesilonis ${ }^{6}$, and Wayne C Zipperer ${ }^{4}$
}

Riparian areas are hotspots of interactions between plants, soil, water, microbes, and people. While urban land use change has been shown to have dramatic effects on watershed hydrology, there has been surprisingly little analysis of its effects on riparian areas. Here we examine the ecology of urban riparian zones, focusing on work done in the Baltimore Ecosystem Study, a component of the US National Science Foundation's Long Term Ecological Research network. Research in the Baltimore study has addressed how changes in hydrology associated with urbanization create riparian "hydrologic drought" by lowering water tables, which in turn alters soil, vegetation, and microbial processes. We analyze the nature of past and current human interactions with riparian ecosystems, and review other urban ecosystem studies to show how our observations mirror those in other cities.

Front Ecol Environ 2003; 1(6): 315-321

Riparian areas are hotspots of ecological function in many landscapes (Naiman and Decamps 1997; Ewel et al. 2001; McClain et al. 2003). Because they occur at the land-water junction alongside natural waterways, they form unique ecosystems that act as "buffer zones" between uplands and streams (Hill 1996; Lowrance 1998). Research on riparian ecology has been diverse, and includes analysis of the habitat requirements of rare plant and animal species, prevention of pollutant movement from uplands into streams, and the regulation of stream temperature and physical structure (Sweeney 1992; Cirmo and McDonnell 1997). Human influences are also pronounced in riparian zones, ranging from extreme

\section{In a nutshell:}

- Urbanization has dramatic effects on the ecology of riparian zones

- Changes in hydrology associated with urbanization create riparian "hydrologic drought" by lowering water tables, which in turn, alters soil, vegetation, and pollutant removal functions

- Riparian zones can be sources rather than sinks for nitrate in urban watersheds

- Riparian zones are foci for human-nature interactions and can serve as catalysts for ecological and socioeconomic revitalization in urban ecosystems

\footnotetext{
${ }^{1}$ Institute of Ecosystem Studies, Box AB, Millbrook, NY 12545; ${ }^{2}$ Department of Geography and Environmental Engineering, Johns Hopkins University, Baltimore, MD 21218; ${ }^{3}$ Department of Geography, University of North Carolina, Chapel Hill, NC 27599; ${ }^{4}$ Northeastem Research Station, USDA Forest Service, Syracuse, NY 13210; ${ }^{5}$ Northeastem Research Station, USDA Forest Service, South Burlington, VT 05403; ${ }^{6}$ Center for Urban Environmental Research and Education, University of Maryland Baltimore County, Baltimore MD 21227
}

manipulation for transportation, energy generation, and agricultural needs to a desire to maintain the ecological functions listed above.

The vast majority of riparian ecological research has concentrated on agricultural and forested watersheds, and there has been particular interest in the ability of riparian zones to prevent the movement of nitrate $\left(\mathrm{NO}_{3}^{-}\right)$from agricultural uplands into coastal waters (Lowrance et al. 1997; Mitsch et al. 2001). Nitrate, a by-product of fertilizer use, human waste treatment, and fossil fuel combustion, is a highly mobile ion and is the most common groundwater pollutant in the US (USEPA 1990; Boyer et al. 2002). Coastal (salt) waters are especially susceptible to $\mathrm{NO}_{3}^{-}$induced eutrophication, the excessive growth and decomposition of algae that leads to low oxygen levels in bottom waters (Diaz 2001).

In this paper we review the effects of urbanization on the structure and function of riparian ecosystems. Urbanization is one of the most dramatic and dynamic global human alterations of ecosystems (Grimm et al. 2000; Pickett et al. 2001). The most marked effects are on hydrology and streams, with impervious surfaces altering the rates and pathways of water movement into, through, and out of ecosystems (Arnold and Gibbons 1996; Paul and Meyer 2001). Although there have been many studies on the effects of urban hydrologic changes on the physical, chemical, and biological properties of streams, very few have addressed riparian ecosystems. While several authors have suggested that urbanization leads to "disconnection from and loss of floodplains" (Riley 1998; Booth et al. 2001; CWP 2003), there have been no systematic analyses of effects on riparian ecosystem structure and function.

Much of the research that we review in this paper comes from the Baltimore Ecosystem Study (BES) (http://beslter.org), one of two urban study sites in the US 
National Science Foundation's Long Term Ecological Research (LTER) network. We also review results from other long-term studies of urban ecosystems, particularly work in the Seine watershed in France and in the Puget Sound area near Seattle, Washington. Riparian research has emerged as an integrative topic in the BES, with studies addressing how changes in hydrology associated with urbanization have altered soil, vegetation, and microbial processes, the history of human use and abuse of riparian ecosystems, and the effects of stream restoration on habitat and water quality. Many of our findings mirror those seen in other urban studies, but one of our main objectives is to highlight the fact that urban riparian ecology is a topic that requires further study in urban areas across the globe.

\section{Riparian history}

Given that access to water for drinking, irrigation, and transportation has a strong influence on the development of human settlements, it is not surprising that riparian areas have complex histories of human activities, with varied effects on ecosystem structure and function. The Gwynns Falls watershed in Baltimore, MD, and the Seine watershed in France are good examples of these complex histories.

\section{Gwynns Falls}

Much of the BES research is centered on the Gwynns Falls (falls is a local term for stream) drainage (Figure 1), a 17 150-ha watershed that stretches from the urban core of Baltimore City to its rural/suburban fringe. Human interactions with the riparian zone have shifted from an early emphasis on transportation (up to the early 1700s) to an extended and persistent period of industrial use (1730-present), and finally to recent use as parks and green space.

Early settlement of the Baltimore region was largely concentrated on areas immediately adjacent to navigable waters, as the value of riparian areas was recognized. Mill Haven, a small, strategically named parcel of land near the mouth of the falls, was granted by the English king in 1696. In 1732, Mill Haven was incorporated into Georgia, a property of the Baltimore Company, an iron refining operation (Johnson 1953; Figure 2). The 1732 Georgia boundaries were contorted to include unclaimed riparian areas. This early industrial activity probably lead to forest clearance for charcoal and cropping throughout much of the lower Gwynns Falls drainage, resulting in relatively early cycles of upland soil erosion and riparian deposition.

Soon after the formation of the Baltimore Company, mills were established along much of the stream (McGrain 1980). Worker housing was built close to the mills in or near the riparian areas. Later, as the manufacturing process became more power intensive, extensive "mill races" (channels to facilitate water movement in and out of industrial facilities) were engineered. This level of engineering and water diversion altered riparian hydrology in the river throughout much of the 1800s. Human habita-

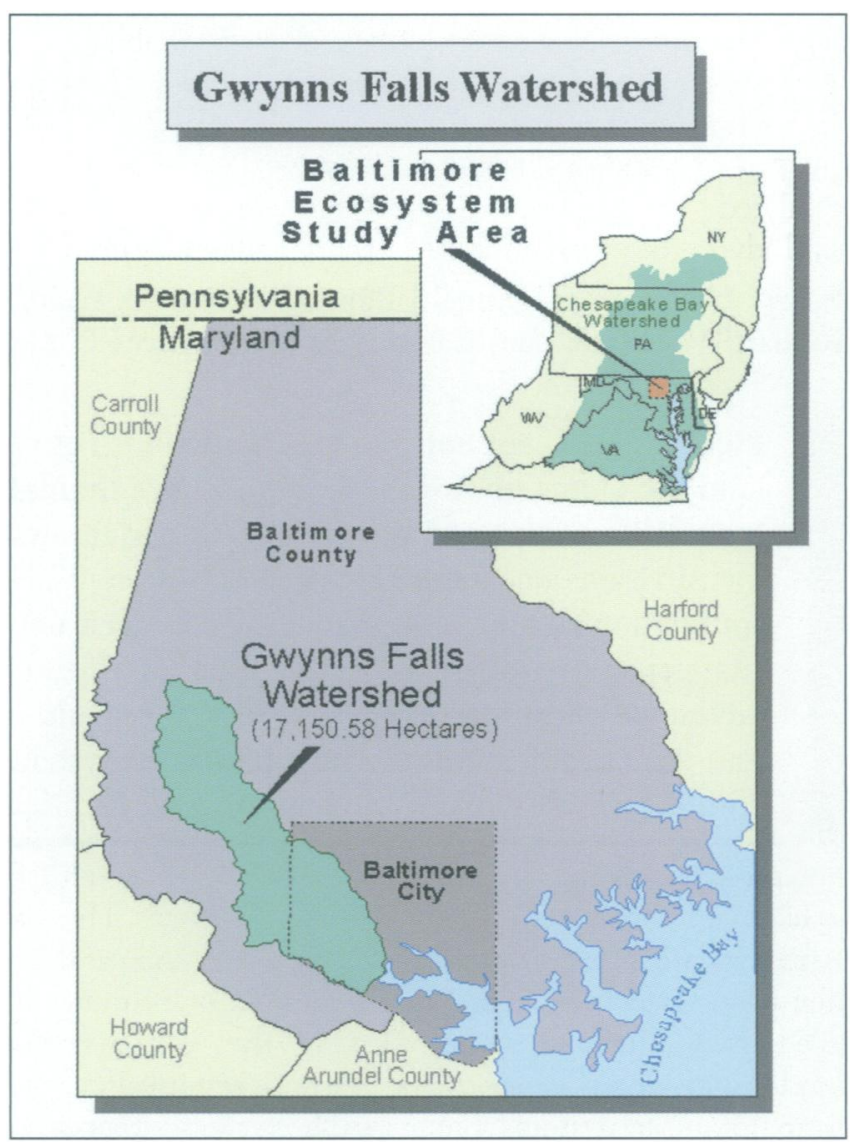

Figure 1. Baltimore urban LTER (Baltimore Ecosystem Study) study area in the Mid-Atlantic region of the US.

tion and continued sedimentation from upland crop production probably altered the chemistry and geomorphology of the floodplains.

The watershed continued to support industrial development well into the 1900s, as a place for convenient, inexpensive waste disposal. There was particular concern about the discharge of meat-packing wastes directly into the stream. In 1881, the owners of the Mt Clare Mill, near the mouth of the stream, sued upstream meat packers because "this blood and offal, naturally and necessarily by the flow of the stream, makes its way into the appellants mill race ... whereby the water in the race and its banks are mixed with and covered by said animal matter ... the said matter decomposing and creating an offensive smell" (McGrain 1985). The massive loading of untreated waste into the Gwynns Falls drainage throughout the 1800 s is difficult to compare with the current setting, where even non-point sources are regulated.

As the valley continued to be developed for industrial purposes, flood risks to riparian property grew. A flood in 1868 killed at least 100 people and destroyed manufacturing facilities throughout the area. Hurricanes Agnes (1972) and David (1979) inflicted millions of dollars of damage in the Gwynns Falls valley alone. With the advent of cheaper fossil fuel energy sources and stricter waste disposal regulations, the risk of losses to flooding began to outweigh the necessary capital reinvestments in 
riparian industrial facilities. Many former establishments were abandoned and, after 1972, most riparian industrial and residential activity ended.

The Olmstead brothers, famous landscape architects, analyzed the Baltimore regional park system in 1904 and advocated purchase of the Gwynns Falls valley from mouth to city limits for use as parkland. The complete purchase of this land was never completed, as industrial activity was still quite strong at that time. Now, nearly a century later, with much of the former agricultural and industrial activity gone, the Revitalizing Baltimore project has developed a parkland trail running from the mouth of the Gwynns Falls to the city (see below), much as the Olmstead brothers envisioned.

\section{The Seine River}

Human activity in the watershed of the middle reach of the Seine River, upstream from Paris, dates from the Bronze Age. This watershed has been the subject of a multidisciplinary research program since 1989 (Benjoudi et al. 2002), with a major focus on riparian wetlands. The watershed's history includes extensive manipulation of the stream and riparian areas for cultivation and transport of hay, timber floating, mills (of which there were already 6000 by 1290), and flood control. Between 1948 and 1997, there was a marked decrease in wetlands and an increase in cultivated and built-up areas.

The riparian history of the Seine is similar to that of Gwynns Falls in the development of mills and the need for waste disposal, but differs in that there is more emphasis on transport (the Seine is larger) and cultivation in the floodplain (the Seine's is broader). Perhaps most interesting is a similar recent focus on aesthetics and recreation. Benjoudi et al. (2002) have proposed the creation of large areas of nature reserve in the watershed. This focus is driven by a common recognition of the unique ecosystem structure and function of riparian areas, and the fact that there are ample opportunities for human-nature interactions there.

\section{Hydrologic changes and urbanization}

The most obvious hydrologic changes associated with urbanization are the engineering of stream channels, in which natural features are replaced by concrete channels and streambank stabilization efforts designed to resist increased flood flows. Extensive piped storm drainage networks often completely bypass riparian zones, channeling large amounts of water from impervious surfaces directly into streams, both quickly and with increased frequency (Paul and Meyer 2001; CWP 2003). A result of this altered hydrology is that incision or "downcutting" is a common feature of urban stream channels (Wolman 1967; Henshaw and Booth 2000). Downcutting results from large volumes of water scouring out sediment that has accumulated during agricultural activity and/or residential construction in the watershed (Figure 3). Incision

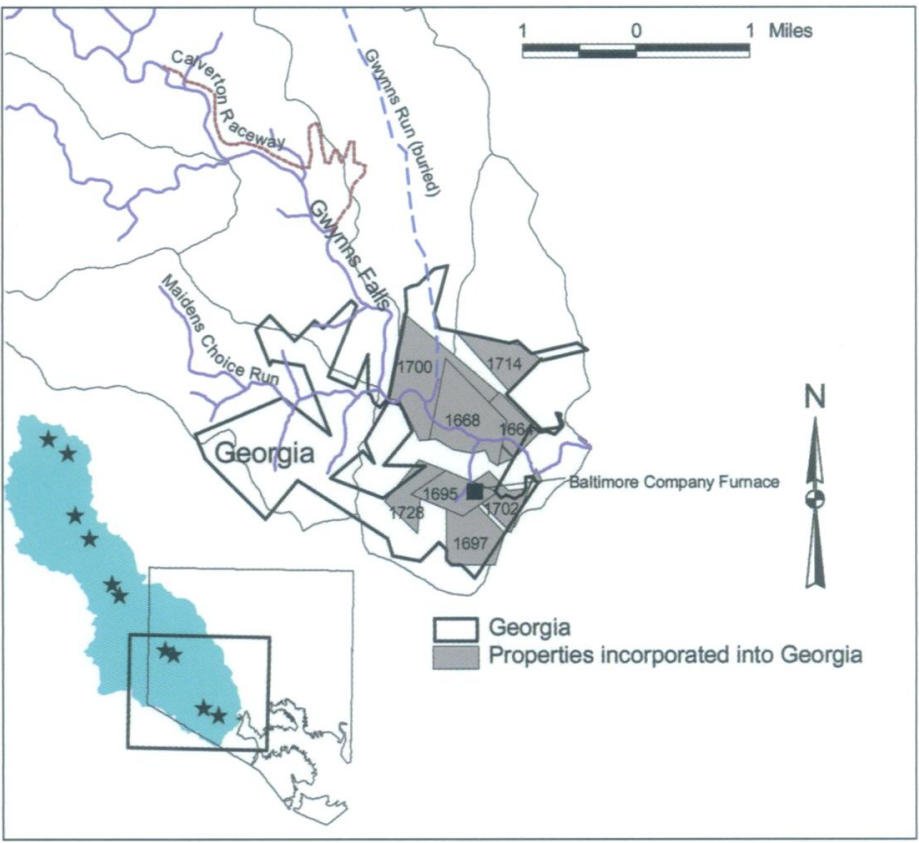

Figure 2. Early colonial land use in the lower portion of the Guynns Falls watershed. Inset: location of the larger map in relation to Baltimore City and the watershed, and the locations of the ten mills established by 1776 (stars). Gray areas: properties incorporated into Georgia (thick line) in 1732; years of earlier grants are indicated on the properties. Note the emphasis of the Georgia claim on riparian zones (compare to the earlier grants adjacent to water.) Dotted lines show the approximate paths of the buried Gwynns Run and the Calverton Raceway, both major engineered disruptions of the riparian hydrology.

is especially marked in watersheds with old and/or stable urban land use, where there are few sources of sediment to replace material scoured by high flows. There is therefore tremendous variability in the condition of urban streams, depending on historic patterns of development, redistribution of sediments within streams, and hydrogeologic conditions in the watersheds (Booth 1990; Trimble 1997; Pizzuto et al. 2000). However, we suggest that, over time, urban watersheds move towards stable land use, with large amounts of impervious cover and low sediment production leading to stream incision in most locations. This trend is less likely to occur in large rivers, such as the Seine, where the need to maintain high flows for navigation results in the construction of hydrologic controls such as dams, locks and spillways that prevent incision.

Stream incision, in combination with reduced infiltration in impervious urban uplands, can reduce riparian groundwater levels (Figures 3 and 4), which can have dramatic effects on soil, plants, and microbial processes. As discussed below, water table level is critical in the control of riparian ecosystem structure and function. It influences soil type, for example the presence of wetland or hydric soils (ie wet, with high levels of organic matter), plant communities (wetland and upland/wetland transition plants) (Gold et al. 2001), and the unique fauna (eg salamanders) that depend on the presence of specific soils and plants (Bodie 2001; Groom and Grubb 2002). 


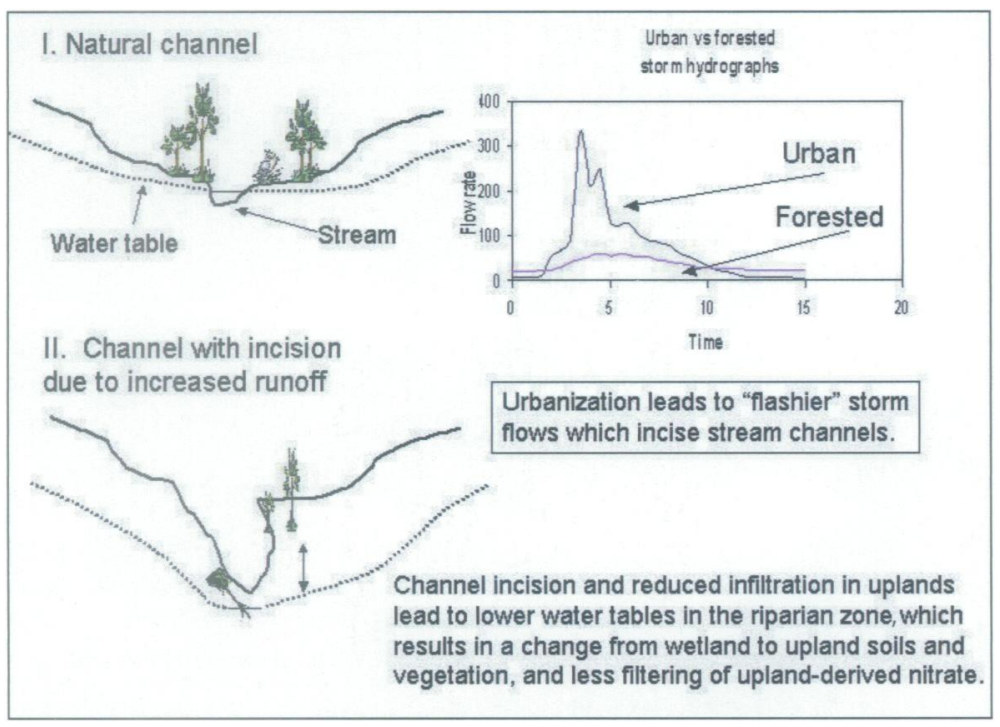

Figure 3. Conceptual diagram showing streams and associated riparian zones in forested and urban watersheds. High runoff during storms leads to incised stream channels in urban watersheds, which, in combination with reduced infiltration in impervious urban uplands, can lead to reduced riparian groundwater levels.

Groundwater level is also a key controller of the ability of riparian zones to prevent the movement of pollutants from uplands into streams, by regulating the interaction of groundwater-borne $\mathrm{NO}_{3}^{-}$with near-surface soils supporting plants and microbial processes that consume this ion (Gold et al. 2001; Figure 5). We suggest that riparian "hydrologic drought", caused by lowered water tables, is a general effect of urbanization that probably occurs in many cities. However, further observations are necessary to verify this.

\section{Urban riparian soils}

The hydric soils common in riparian wetlands are characterized by a series of visual "redoximorphic" features that

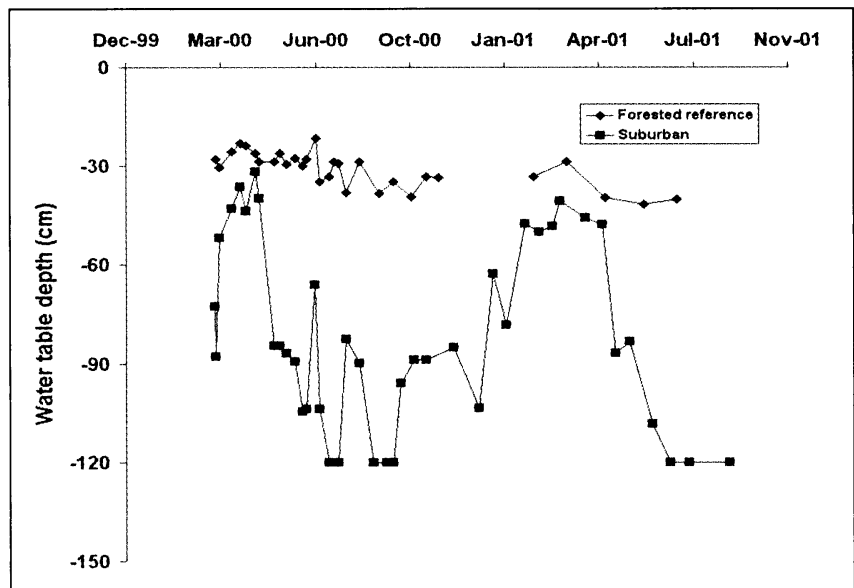

Figure 4. Water table depth at forested reference and urban riparian sites with similar geomorphic characteristics in Baltimore, MD from Feb 2000-Sept 2001. Values are mean of four wells along two transects at each site. Adapted from Groffman et al. (2002). are a product of chemical reactions, primarily the oxidation, reduction, and solubilization of iron (SSS 1992). Under anaerobic conditions, iron is reduced, solubilized, and leached away, producing grey (gleyed) colors in the soil profile. Redoximorphic features are used to classify soil "drainage classes" that index long-term average water table conditions at a site (Reddy and Patrick 1993). Since these features take many years to develop and change, they are poor indicators of short-term water table dynamics, and they often persist for many years in sites where water tables have dropped (eg urban watersheds).

Hydrologic changes resulting from urbanization cause soil patterns in urban riparian zones to diverge from the idealized case shown in Figure 5 (Pouyat and Effland 1998; DeKimpe and Morel 2000). For example, the lowering of the water table associated with urbanization can create aerobic conditions in soils that have been mapped as hydric. Moreover, dynamic cycles of erosion and deposition in watersheds can alter the normal sequence of horizons (layers) in riparian zone soils (Nakamura et al. 2000; Stolt et al. 2001). In agricultural watersheds, high levels of erosion and frequent flooding lead to increased sedimentation in the riparian zone, which buries surface organic horizons. In a survey of riparian soils in the Gwynns Falls watershed, which was previously dominated by agriculture, we observed numerous buried surface horizons and evidence of relic redoximorphic features near what was once the surface organic horizon (Figure 6). The combination of increased sedimentation and the lowering of the water table has necessitated a change in the drainage classification of these soils, with the loss of a hydric soil designation in many cases.

Alteration of riparian soil profiles can have dramatic effects on processes that produce and consume $\mathrm{NO}_{3}{ }^{-}$. We have observed high levels of $\mathrm{NO}_{3}^{-}$and nitrification (a microbial process that produces $\mathrm{NO}_{3}{ }^{-}$) and low rates of denitrification (an anaerobic process that consumes $\mathrm{NO}_{3}{ }^{-}$) in aerobic, urban riparian soil profiles with water tables that are deep in comparison to forested reference watershed riparian soils with shallow water tables (Groffman et al. 2002; Figures 5 and 7). These results suggest that soil and hydrologic changes associated with urbanization can cause riparian zones to be sources rather than sinks for $\mathrm{NO}_{3}{ }^{-}$in urban watersheds, but these results need to be verified in other watersheds.

\section{Urban riparian vegetation}

Vegetation plays a number of critical roles in riparian zones, including maintenance of stream temperature, provision of woody debris to create stream habitat, and uptake of $\mathrm{NO}_{3}^{-}$from shallow groundwater (Sweeney 1992; Tabacchi et al. 2002). Given that the regeneration and growth of riparian vegetation is adapted to water table lev- 
els and the flooding regime of the adjacent stream, the hydrologic and soil changes associated with urbanization described above should have dramatic effects on riparian vegetation.

In the BES, we have examined natural and human-altered links between hydrology, soil, and vegetation in riparian zones. Comparisons of vegetation between the rural/suburban (upper) and urban (lower) sections of the watershed show distinct patterns across an urban to rural gradient (Brush and Zipperer unpublished). In the lower, more urbanized section of the watershed, wetland tree species are either absent or occur as small stems, while upland species are abundant and occur in mixed sizes. A comparison of the number of wetland and upland species in the mostly urbanized Gwynns Falls riparian zone versus the non-urbanized Piedmont floodplains throughout Maryland (Brush et al. 1980) shows approximately twice as many upland species in the urban floodplains than in the non-urbanized floodplains. The majority of shrubs in riparian zones through the Gwynns Falls watershed are upland species. For herbaceous species, frequencies of upland and wetland species are about equal in the upper and middle regions of the watershed, but upland species are more than twice as common in the more urban lower floodplains.

Our vegetation analysis clearly shows the effect of riparian hydrologic drought induced by urbanization. The riparian zone is becoming drier throughout the Gwynns Falls watershed, with the lower urbanized watershed providing the driest habitats, which are more favorable for germination and growth of upland species. Such a shift could have dramatic effects on ecosystem services provided by vegetation in the riparian system. Long-term research will probably reveal a similar loss of wetland riparian species, as similar hydrologic changes accompany suburban and urban development in the upper reaches of the watershed.

In addition to our work in Baltimore, many other studies have shown that wetland vegetation responds rapidly to hydrologic changes. Alterations in riparian vegetation induced by urban hydrologic drought are a particularly important type of wetland vegetation effect, because of the functional importance of riparian zones in watersheds. For example, such change has been identified as a key factor in stream degradation in the Puget Sound/Seattle metropolitan area of Washington State. In a survey of 45 sites along second- and third-order streams, measures of stream biotic integrity declined strongly with the percentage of urban land cover in the riparian zone (Booth et al. 2001).

\section{Human riparian ecosystems}

Urbanization is a human-driven process, so research in urban riparian ecology must consider human values and behavior. The integration of social science with physical and biological sciences is one of the challenges being addressed in the new urban LTER sites and in other urban ecology research efforts.

In the BES, we use the "Human Ecosystem Framework" to integrate the three disciplines (Grove and Burch 1997). The framework outlines interactions between critical biophysical resources (eg soil, water, vegetation) and social drivers that depend on and influence these resources. An example of an integrative "human riparian ecosystem" approach in action is the creation of the Gwynns Falls Trail, a 14-mile stream-valley trail system, which opened in June 1999. The trail (www.gwynnsfallstrail.org) connects over 30 neighborhoods in west and southwest Baltimore with parklands, unique urban environmental features, cultural resources, and historic landmarks.

The creation of the Gwynns Falls Trail is an excellent example of how social, physical, and biological sciences can be integrated in an effective way in an urban ecosystem. The motivation for its creation was social and biophysical degradation. A US Army Corps of Engineers study had chronicled extensive degradation of streams and riparian zones in Baltimore City, including poor riparian and instream habitat, streambank and bed stability problems, and inferior water quality. At the same time, neighborhoods were undergoing socioeconomic decline; nearly $50 \%$ of the population of Baltimore City was lost between 1940 and 1990, leaving over 60000 abandoned houses and lots. In 1994, the US Forest Service established the Revitalizing Baltimore project, which included community forestry, watershed restoration, and educational projects centered on conservation stewardship and outdoor experiences. One of the main objectives of the project was to develop the idea that ecological revitalization can stimulate socioeconomic revitalization by bringing people in underserved (poor) neighborhoods together through community forestry and stream restoration projects. These projects foster commu- 


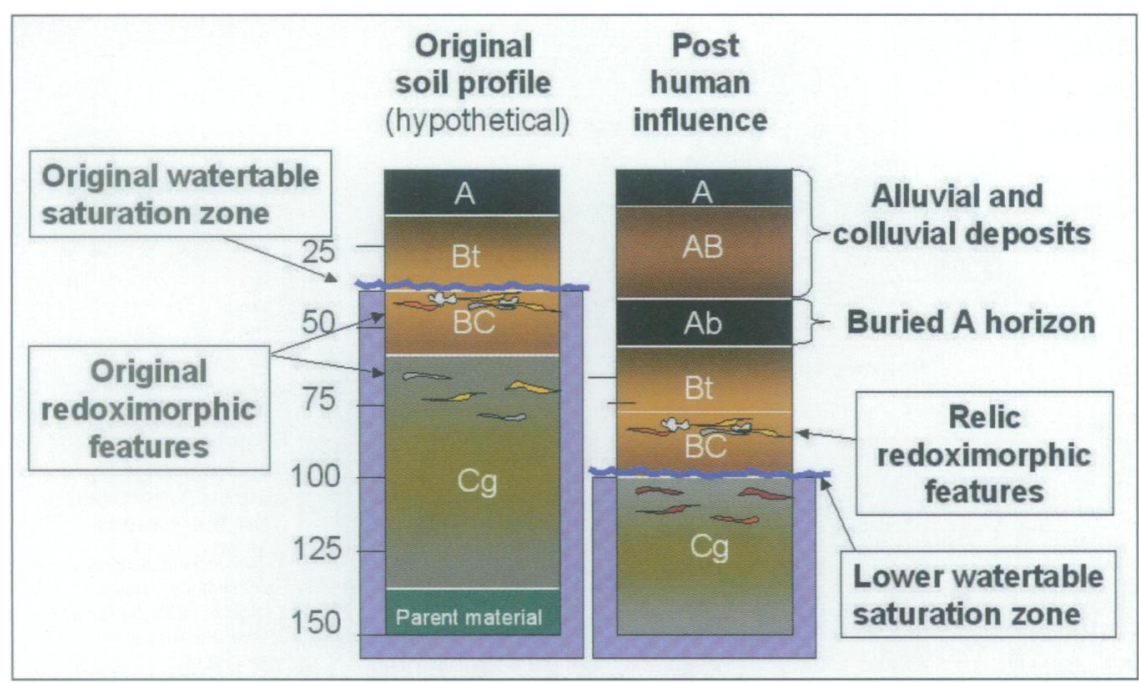

Figure 6. Profiles of riparian zone soils before and after enhanced rates of sediment deposition associated with agriculture and residential construction, and lowered water tables associated with urbanization. ian zone, they become aware of this unique and valuable natural resource, which increases demand for maintaining the resource. Humans are thus functioning as a regulatory feedback mechanism in the ecosystem, in the same way that a complex web of interactions maintains stability (resistance and resilience) in unmanaged forest ecosystems (Bormann and Likens 1979).

As with hydrology, soil, and vegetation, the human ecology of riparian zones varies from city to city. Along the middle reach of the Seine River in France, human riparian ecology centers on balancing needs for flood control, agriculture, and conservation (Benjoudi et al. 2002). There is interest in establishing a nature preserve to protect riparian wetlands and increase human internity cohesion, which leads to community interest in improved city services. The increase in services, in turn, leads to improvements in environmental and socioeconomic conditions and creates positive feedback for neighborhood revitalization, reversing the negative spiral of population loss, environmental and social degradation, and further population loss.

The idea for the Gwynns Falls Trail emerged from a series of stream restoration projects, and was intended to serve as a highly visible focal point for stream and neighborhood revitalization in Baltimore City. The project was brought to fruition by the Parks and People Foundation, a non-profit group working at the interface between humans and the environment, and which focuses on creating recreational opportunities for Baltimore City residents. The foundation coordinated fundraising activities by multiple groups, and the trail was opened with great fanfare in 1999.

As more people use the trail, important feedbacks develop. Once they have experienced the stream and ripar- action with the riparian zone though hiking trails, fishing zones, and boating, similar to what has been created in Baltimore. In the Puget Sound/Seattle area, human riparian ecology research is focusing on the behavior of individuals who manage land in the riparian zone (Booth et al. 2001). Research has shown that the ability of regional planning and management experts to predict individual behaviors is limited. These behaviors have a strong effect on riparian vegetation, and therefore on stream biotic integrity. A major challenge in human riparian ecology in cities around the world will be to reconcile these individual behaviors, which operate on a local scale, with the larger, watershed-scale hydrologic changes associated with urbanization, which also influence soil and vegetation processes at the local scale.

\section{Acknowledgements}

The Baltimore Ecosystem Study project is supported by the National Science Foundation Long-Term

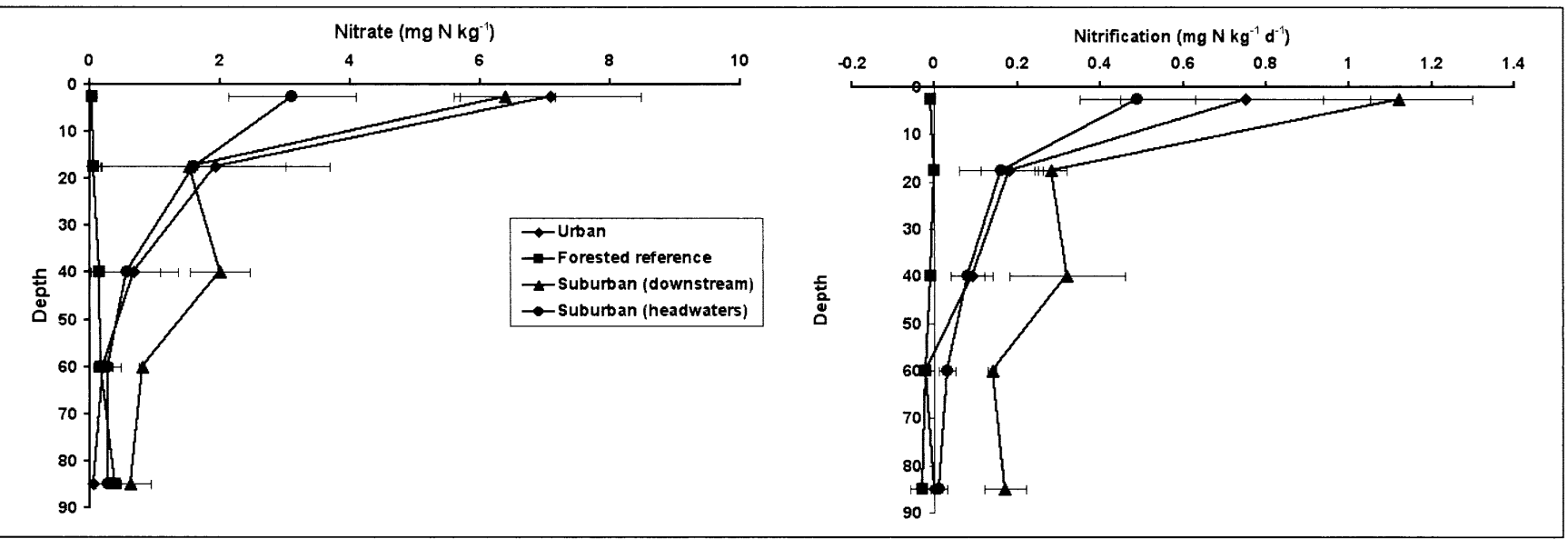

Figure 7. Soil nitrate (left) and potential net nitrification (right) in soil profiles at four riparian sites in Baltimore, MD. Values are mean (standard error) of two riparian transects at each site $(n=2)$. Each transect consisted of two sampling locations $5 \mathrm{~m}$ from the streambank on opposite sides of the stream. Adapted from Groffman et al. (2002). 
Ecological Research program (grant DEB 9714835) and by the EPA-NSF joint program in Water and Watersheds (project GAD R825792). The National Science Foundation supported the historical analysis through a Graduate Research Fellowship given to Daniel J Bain.

\section{References}

Arnold CL and Gibbons JC. 1996. Impervious surface coverage: the emergence of a key environmental indicator. J Am Plant Assoc 62: 243-58.

Benjoudi H, Weng P, Guérin R, and Pastre JF. 2002. Riparian wetlands in the middle reach of the Seine River (France): historical development, investigation and present hydrologic functioning. A case study. J Hydrol 263: 131-55.

Bodie JR. 2001. Stream and riparian management for freshwater turtles. J Environ Manage 62: 443-55.

Booth DB. 1990. Stream-channel incision following drainagebasin urbanization. Water Resour Bull 26: 407-17.

Booth DB, Karr JR, Schauman S, et al. 2001. Urban stream rehabilitation in the Pacific Northwest. Wash Water Resour 12: 1-11.

Bormann FH and Likens GE. 1979. Pattern and process in a forested watershed. New York: Springer-Verlag.

Boyer EW, Goodale CL, Jaworski NA, and Howarth RW. 2002. Anthropogenic nitrogen sources and relationships to riverine nitrogen export in the northeastern USA. Biogeochemistry 57: 137-69.

Brush GS, Lenk C, Smith J. 1980. The natural forests of Maryland: an explanation of the vegetation map of Maryland (with 1:250,000 map). Ecol Monogr 50: 77-92.

Brush GS and Zipperer WC. Riparian vegetation along an urban-rural gradient. Unpublished data.

CWP (Center for Watershed Protection). 2003. Impacts of impervious cover on aquatic systems. Research Monograph No. 1. Ellicot City, MD: Center for Watershed Protection.

Cirmo CP and McDonnell JJ. 1997. Linking the hydrologic and biogeochemical controls of nitrogen transport in near-stream zones of temperate-forested catchments: a review. J Hydrol 199: 88-120.

DeKimpe CR and Morel JL. 2000. Urban soil management: a growing concern. Soil Sci 165: 31-40.

Diaz RJ. 2001. Overview of hypoxia around the world. J Environ Qual 30: 275-81.

Ewel KC, Cressa C, Kneig RT, et al. 2001. Managing critical transition zones. Ecosystems 4: 452-60.

Gold AJ, Groffman PM, Addy K, et al. 2001. Landscape attributes as controls on groundwater nitrate removal capacity of riparian zones. J Am Water Resour As 37: 1457-64.

Grimm NB, Grove JM, Pickett STA, and Redman CL. 2000. Integrated approaches to long-term studies of urban ecological systems. BioScience 50: 571-84.

Groffman PM, Boulware NJ, Zipperer WC, et al. 2002. Soil nitrogen cycle processes in urban riparian zones. Environ Sci Tech. 36: 4547-52.

Groom JD and Grubb TC. 2002. Bird species associated with riparian woodland in fragmented, temperate deciduous forest. Conserv Biol 16: 832-36.

Grove JM and Burch WR Jr. 1997. A social ecology approach and applications to urban ecosystem and landscape analyses: a case study of Baltimore, Maryland. Urban Ecosyst 1: 259-75.

Henshaw PC and Booth DB. 2000. Re-equilibration of stream channels in urban watersheds. J Am Water Resour As 36: 1219-36.
Hill AR. 1996. Nitrate removal in stream riparian zones. J Environ Qual 25: 743-55.

Johnson K. 1953. The genesis of the Baltimore Ironworks. J Southern Hist 19: 157-79.

Lowrance R. 1998. Riparian forest ecosystems as filters for nonpoint-source pollution. In: Pace ML and Groffman P (Eds). Successes, limitations and frontiers in ecosystem science. New York: Springer-Verlag.

Lowrance R, Altier LS, Newbold JD, et al. 1997. Water quality functions of riparian forest buffers in Chesapeake Bay watersheds. Environ Manage 21: 687-712.

McClain ME, Boyer EW, Dent CL, et al. 2003. Biogeochemical hot spots and hot moments at the interface of terrestrial and aquatic ecosystems. Ecosystems. 6: 301-12.

McGrain JW. 1980. Grist mills in Baltimore County, Maryland. Towson, MD: Baltimore County Public Library.

McGrain JW. 1985. From pig iron to cotton duck: a history of manufacturing villages in Baltimore County. Towson, MD: Baltimore County Public Library.

Mitsch WJ, Day JW Jr., Gilliam JW, et al. 2001. Reducing nitrogen loading to the Gulf of Mexico from the Mississippi River basin: strategies to counter a persistent ecological problem. BioScience 51: 373-88

Naiman RJ and Decamps H. 1997. The ecology of interfaces riparian zones. Annu Rev Ecol Syst 28: 621-58.

Nakamura F, Swanson FJ, and Wondzell SM. 2000. Disturbance regimes of stream and riparian systems: a disturbance-cascade perspective. Hydrol Process 14: 2849-60.

Paul MJ and Meyer JL. 2001. Streams in the urban landscape. Annu Rev Ecol Syst 32: 333-65.

Pickett STA, Cadenasso ML, Grove JM, et al. 2001. Urban ecological systems: linking terrestrial ecological, physical, and socioeconomic components of metropolitan areas. Annu Rev Ecol Syst 32: 127-57.

Pizzuto JE, Hession WC, and McBride M. 2000. Comparing gravelbed rivers in paired urban and rural catchments of southeastern Pennsylvania. Geology 28: 79-82.

Pouyat RV and Effland WR. 1998. The investigation and classification of human modified soils in the Baltimore Ecosystem Study. In: Kimble J (Ed). Classification, correlation, and management of anthropogenic soils. Lincoln, NB: USDA Natural Resource Conservation Service.

Reddy KR and Patrick WH. 1993. Wetland soils: opportunities and challenges. Soil Sci Soc Am J 57: 1145-47.

Riley AL. 1998. Restoring streams in cities: a guide for planners, policy makers, and citizens. Washington, DC: Island Press.

SSS (Soil Survey Staff). 1992. Keys to Soil Taxonomy, 5th Ed. Soil Management Support Services Technical Monograph 19. Blacksburg, VA: Pocahontas Press.

Stolt MH, Genthner MH, Daniels WL, and Groover VA. 2001. Spatial variability in Palustrine wetlands. Soil Sci Soc Am J 65: 527-35.

Sweeney BW. 1992. Streamside forests and the physical, chemical, and trophic characteristics of Piedmont streams in eastern North America. Water Sci Technol 26: 2653-73.

Tabacchi E, Lambs L, Guilloy H, et al. 2002. Impacts of riparian vegetation on hydrological processes. Hydrol Process 14: 2959-76.

Trimble SW. 1997. Contribution of stream channel erosion to sediment yield from an urbanizing watershed. Science 278: $1442-44$

USEPA (US Environmental Protection Agency). 1990. National pesticide survey: nitrate. Washington, DC: Office of Water, Office of Pesticides and Toxic Substances..

Wolman MG. 1967. A cycle of sedimentation and erosion in urban river channels. Geogr Ann A 49: 385-95. 